\title{
CARACTERIZAREA TEHNOLOGIEI DE PASTĂ A CERAMICCII STARCEVO-CRIŞ DE LA ŞIMNIC
}

Gheorghe Gâţă

Doina Galbenu

Fără îndoială meșterii olari neolitici au fácut ceramica după o tehnologie empirică cu o succesiune bine definită de rețete pentru alegerea materiilor prime, frământarea pastei, modelarea, uscarea, ornamentarea, arderea şi răcirea vaselor.

Lucrarea de faţ̌̆, folosind ceramica Starcevo-Criş de la Simnic (Oltenia) ${ }^{1}$ prezintă reţete privind alegerea luturilor pentru pastă ${ }^{2}$ şi degresarea pastei în vederea modelării vaselor.

Aşezarea arheologică de la Şimnic, amplasată pe un bot de terasă din apropierea luncii Jiului, a fost descoperită în 1962 cu ocazia unor gropi pentru fundaţia unui siloz. Săpăturile au fost făcute de Muzeul Olteniei între 1967 - 1971 şi din 1972 de Muzeul de Istorie al RSR ${ }^{3}$. Săpăturile au descoperit material arheologic aparţinând culturilor Starcevo-Criş, Vinca, Sălcuţa şi Cernavoda Dobroteşti. Lucrările agricole şi apele de şiroire au distrus nivelele Coţofeni şi probabil cele din epoca feudală timpurie (secolele VI - VII d. Chr.).

Stratul de cultură Starcevo-Criş de la Simnic cuprinde trei nivele ${ }^{4}$ identificate şi de Marin Nica la Grădinile în punctul "La Izlaz".

Nivelul al treilea, cel mai bogat în materiale arheologice la Simnic ${ }^{6}$, considerat că datează din timpul fazei Starcevo III după periodizarea lui VI. Milojcic ${ }^{7}$ are o pastă cu mai mult nisip și este aspră la pipăit. Acest nivel a fost identificat de Eugen Comşa şi în aşezarea Starcevo-Criş de la Dulceanca cu un acelaşi fel de pastă mai nisipoašr.

Pentru a permite o analiză amănunţită a reţetei de pastă, ceramica Starcevo-Criş de la Simnic a fost grupată după modul de prelucrare a feţelor vaselor şi după ornamentaţe în şapte tipuri:

1) Ceramică nepazită de uz comun, ornamentată sau nu cu şiruri de alveole, brâuri aplicate, protuberanţe sau uşor incizatr.

2) Ceramică ornamentată cu vârci.

3) Ceramică ornamentată cu amprente fácute cu unghia sau cu degetul prin imprimare (mimetiç̆).

4) Ceramică lustruită cu angobă roșie ${ }^{\beta}$.

5) Ceramică lustruită cu slip de culoare brună până la negru.

\footnotetext{
${ }^{1}$ Fragmentele ceramice analizate au fost prelevate de Doina Galbenu in campaniile de săpături dintre anii 1967 - 1972 şi 1974.

2 In această lucrare sursele de pasta au fost materiale litologice din deschiderile din imediata apropiere a aşezării.

${ }^{3}$ Doina Galbenu, Asezările neolitice de la Şimnic. 1. Muzeul de Istorie RSR, 1975, p. 9

1 ibidem, p. 18.

${ }^{5}$ Marin Nica, Graddinile, o nouă aşezare a nediticului timpuriu in sud-estul Otteniei. Arhivele Olteniei, SN, 1, 1981, p. 39.

${ }^{6}$ Doina Galbenu, op.cit, p. 23.

7 Marin Nica, op.cit, p. 27.

${ }^{8}$ Separarea după culoare s-a făcut consideránd nuanţele 10R şi 2,5YR pentru tipul 4 şı nuanțele 7,5YR şi 10YR din tabelele Munsell pentru tipul 5.

${ }^{9}$ În această lucrare prin slip se inţelege un stat de acoperire lustruit de pe pereţii vaselor care are aceeași compoziţe cu partea fină a meterialului pastei.
} 
6) Ceramică pictată cu negru-brun pe fond roşu.

7) Ceramică pictată cu negrı-brun pe fond de culoare deschisă.

Aceste tipuri de ceramică au fost separate din necesitatea sistematizării cercetărilor privind precizarea criteriilor tehnice pentru a distinge un lot de ceramică reprezentând aceeaşi tehnolegie de pastă, descoperirea rețetelo ${ }^{10}$, tehnologiilor ceramice şi existenţa uneia sau mai multor rețete de pastă în ceramica Starcevo-Criş de la Simnic.

\section{Sursele de materii prime pentru pastă}

Greutatea transportului şi numărul mare de fragmente ceramice descoperite în aşezarea din neoliticul timpuriu de la Şimnic sugerează că sursele pentru pastă au fost locale. Pentru a preciza aceste surse au fost analizate ${ }^{11}$ atât probe de masă ceramică ${ }^{12}$ a fragmentelor Starcevo-Criş, cât şi probe litologice şi de sol din imediata apropiere a aşezării.

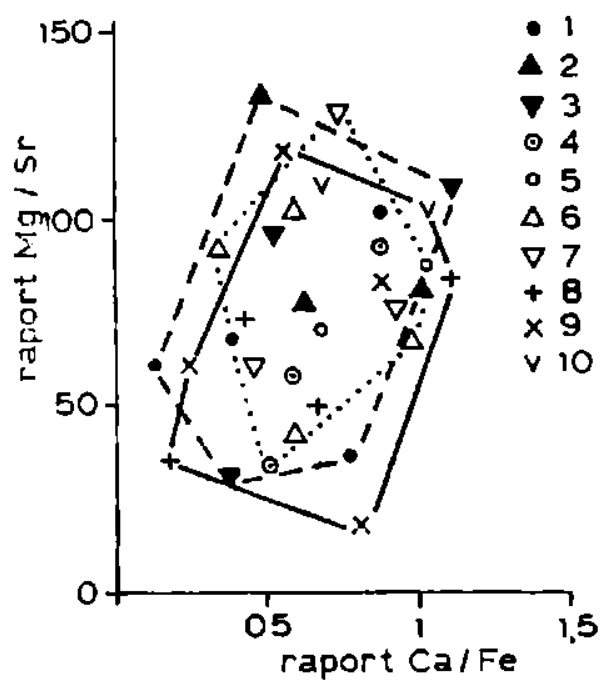

Fig. 1. Repartibia probelor cercetate dupd raportul Mg/Sr si raportul Ca/Fe. Ceramica: 1 - uz comun (bip 1), 2 - cu varai (tip 2), 3 - cu amprente facute $c u$ unghia tip 3), 4 lustruită, angobă roşie (tip 4), 5 - lustruită cu slip brun până la negru (tip 5), 6 - pictată cu negru-brun pe fond roşu (tip 6), 7 - pictate cu negru-brun pe fond de culoare deschisă; Surse pentu pasta cu textura: 8 - nisip-lutoasa, 9 litoasa, 10 - lut-argiloasa. Arealul surselor, ceramicei netezite (bo 1-2-3), ceramices Iustruite (tip 4-5-6-7).

Repartiţia probelor analizate dupð raportul conţinuturilor de magneziu/stronţiu şi calciu/fier arată că arealul probelor luate ca surse prezumtive acoperă arealul probelor luate din fragmentele celor şapte tipuri de ceramică (fig. 1) şi arată că pentru ceramică au fost utilizate astfel de probe litologice din deschiderile din imediata apropiere a aşezării. Mai mult încă arealul probelor de ceramică fină (tipurile 4-5-6-7) este cuprins in arealul probelor de ceramică netezitž (tipurile 1-2-3) şi dovedește prin aceasta o posibilă alegere a materiilor prime pentru pasta ceramicei fine.

În graficul din figura 1 punctele corespunzătoare celor şapte tipuri de ceramică sunt amestecate între ele şi arată că nu a fost ales un anumit material litologic pentru pasta unui anumit tip de ceramică.

Într-o diagramă (fig. 2) care reprezintă repartiția probelor litologice și probelor de masă ceramică după conţinuturile de nisip fin $(0,2-0,02 \mathrm{~mm}$ ) şi nisp grosier (2 $0,2 \mathrm{~mm})^{13}$ arealul surselor prezumtive cuprinde în întregime arealul maselor ceramice ale fragmentelor descoperite in cele trei nivele din aşezarea Starcevo-Criş de la Şimnic. Se confirmă şi pe această cale că probele litologice analizate sunt sursele de materii prime pentru pasta ceramicei cercetate. Faptul că arealul probelor litologice este mult mai

\footnotetext{
${ }^{10}$ Prin reţetă se inţelége un proces parţial in tehnologia de obţinere a ceramicei, o reţetă de pastă, o rețetă de ardere, etc.

${ }^{11}$ A fost utilizat un extras in acid clorhiditic $6 \mathrm{~N}$ timp de 2 orc pe baia de apă, la un raport 19 proba/20 cmc $\mathrm{HCl}$, filtrarea imediat la cald şi spălare cu $\mathrm{HCl} 5 \%$ până la un volum de $100 \mathrm{cmc}$.

12 Toate probele de analizat pentru caracterizarea pastei au fost luate din miezul fragmentelor evitánd interionul şi exteriorul lor.

i3 Analizele granulometrice efectuate după mărunţirea uşoară a probelor, tratarea cu apă oxigenată $6 \%$ şi acid clorhidric $3 \%$ pentru indepărtarea materialului organic şi carbonatilor.
} 
extins decât arealul probelor fragmentelor ceramice arată o posibilă selecție a materiilor prime mai ales după conţinutul lor de nisip grosier.

Punctele provenite din cele trei nivele şi din cele două tipuri de ceramică analizate (mimetică şi pictată cu negru-brun pe roşu) sunt amestecate între ele şi sugerează că nu s-a ales o anumită sursă pentru un anumit tip ceramic după cantitatea de nisip. Totuşi, dacă fragmentele ceramice alese sunt reprezentative pentru ceramica cercetată, atunci în decursul timpului mesterii olari din neolitioul timpuria de la Şimnic au abandonat treptat sursele cu textura mai argiloasă folosite pentru ceramica descoperita în nivelele 1 şi 2 şi au utilizat din ce în ce mai mult surse cu textură mai nisipoasă, mai ales pentru ceramica din nivelul 3 care apare mai aspră la pipăit.

Este puţin probabilă degresarea cu nisip a lutului pentru pastă deoarece există în imediata vecinătate a aşezării multe deschideri cu materiale litologice cu un conţinut de nisip care variază în limite largi, astfel încât acoperă întreg intervalul de concentraţii de nisip din pasta fragmentelor ceramice.

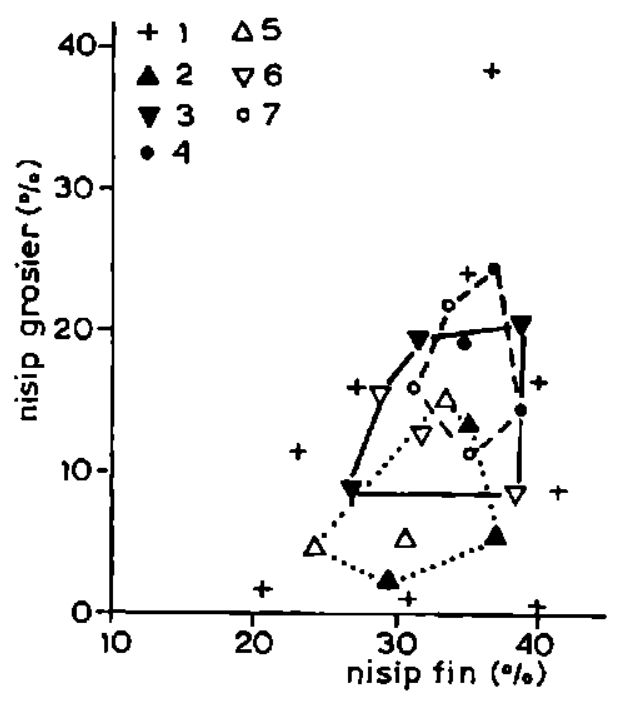

Fig. 2. Repartibja dupa continuturile de nisip fin si nisip grosier a surselor şi a unor fragmente ceramice Starcevo-Criş de la Simnic: 1 - surse, ceramica cu amprente (to 3), 2 - nivel 1, 3nivel 2, 4- nivel 3, ceramică pictata cu negrutrun pe rosu, 5-nived 1, 6- nivel 2, 7-nivel 3.

\section{Pasta ceramică}

Materiile prime sfărâmate, udate cu apă şi frământate formează pasta pentru modelarea vaselor şi figurinelor. Această pastă se poate modela usor dacă are proprietătile de plasticitate adecvate imprimate de un conţ̦inut de argilă smectică ${ }^{14}$ corespunzător.

La materialele litologice analizate ca surse determinarea prin difracția raxelor $X$ a conţinutului de smectit conduce la valori care variază într-un interval larg (7,5 - 39\% smectit). Un grafic (fig. 3) care reprezintă variaţia conţinutului de smectit în funcţie de conţinutul de fracţiune argiloasă (sub $0,002 \mathrm{~mm}$ ) arată că punctele se aşează pe 0 linie dreaptă $(r=0,993)$. Nisipul lutos din punctul A nu dă o pastă care să lege şi să aibă o plasticitate suficientă pentru modelarea vaselor şi probabil nu a fost folosit ca pastă ceramică. De altfel în figura 2 acest punct este mult prea depărtat de arealul maselor ceramice spre conţinuturi mari de nisip (76\%) şi confirmă neutilizerea lui pentru pasta ceramicei Starcevo-Cris de la Şimnic.

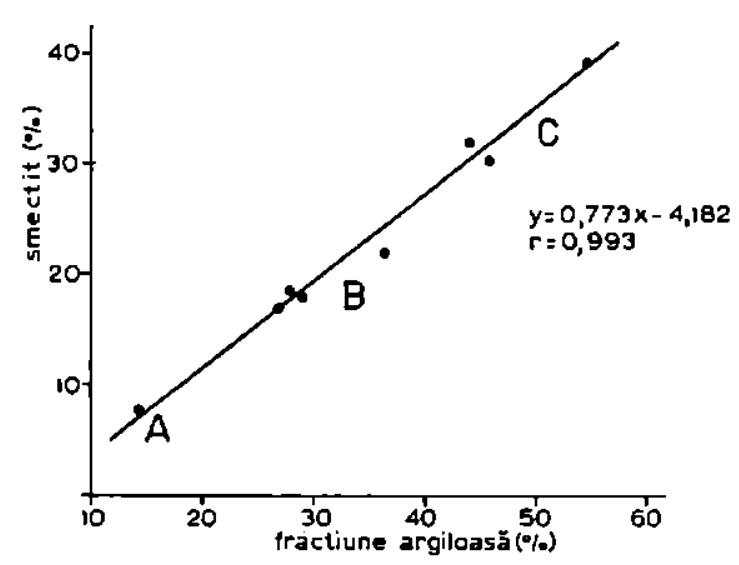

Fig. 3. Variatia confinutului de smectit in functie de continutul de argila (sub $0,002 \mathrm{~mm})$ la sursele de pasto din neoliticul timpuriu de la Simnic.

\footnotetext{
${ }^{14}$ Componenta plastică din argila smectică este smectitul, argilă expandabilă, cu un parametru reticular de 17 Ja saturarea cu etilen-glical.
} 
Probele din arealul B (fig. 3) cu textură lut-nisipoasă până la lutoasă şi cu 17-22\% smectit au suficientă plasticitate pentru a fi folosite la modelarea vaselor și nici nu crapă la uscarea la temperatura ambiantă fiind suficient de degresate de conţinutul de nisip al surselor.

Probele din arealul C (fig. 3) au o plasticitate accentuată şi mai ales proba cu $39 \%$ smectit fisurează la uscarea la temperatnra ambiantž. De aici meșterii olari din neoliticul timpuriu de la Şimnic pentru a evita fisurarea au folosit masă vegetală ca degresant. De fapt această probă de lut-argilos cu $39 \%$ smectit și 54,7\% argilă corespunzătoare punctului din stânga de lângă axa absciselor în figura 2 este destul de depărtat de arealul maselor ceramice Starcevo-Criş şi probabil a fost evitată de meșterii olari din neoliticul timpuriu din aşezare.

\section{Degresarea pastei ceramice}

Variaţia mare a compoziţiei granulometrice şi mineralogice a materialelor litologice folosite ca surse a pus problema degresării pastei meșterilor olari neolitici. După toate probabilităţile populaţiile Starcevo-Criş au adus din alte aşezări tehnologia de pastă odată cu stabilirea la Şimnic. Această tehnologie constă în alegerea lutului şi degresarea cu masă vegetală mărunţită. Majoritatea fragmentelor ceramice au goluri produse de carbonizarea adausului de masă vegetală. Se deosebesc fragmente de tulpini, frunze, pleavă.

Secţiuni subţiri în materialul plastic prezintă goluri tubulare lungi de până la 10-12 mm, uneori sub formă curbată produsă de frământarea pastei. La fragmentele ceramice pictate materialul vegetal a fost mărunţit mai mult ca la restul ceramicei Starcevo-Criş de la Şimnic deoarece dimensiunile golurilor sunt în general mai reduse şi răspândite mal uniform în pastă śemn că și frământarea a fost inai temeinică. Este probabil ca la o bună parte din ceramică cercetată, plantele ierbacee mărunţ̧ite să fi fost adăugate verzi sau recent uscate aşa cum arată fragmentele de tulpini de graminee care nu prezintă rupturi caracteristice paielor uscate.

Această selecţie a surselor a fost practicată timp indelungat din generaţie in generaţie de meşteri olari neolitici aşa cum rezultă din masa ceramică a fragmentelor Starcevo-Criş de la Şimnic. în nivelele 1 şi $2 \mathrm{~s}$-au preferat materiale litologice cu mai multă argilă și textură lut-argiloasă, pe când în nivelul 3 o bună parte din vase a avut o pastă lut-lut nisipoasă deci cu mai mult nisip. Ageasta sugerează că reţeta de pastă a fost adusă la Şimnic dintr-o aşezare care folosea luturi sau luturi argiloase ca surse pentru pastă.

Datorifă cantităţilor mari de smectit în materialele litologice do la Şimnic reţeta adusă a trebuit să fie adaptată la sursele locale. Odată cu stabilirea retetei de pastă şi perfecţionarea condiţiilor de ardere meşterii neolitici au fost nevoiţi să folosească materiale litologice cu mai mult nisip, surse locale care se găseau din abundenţă în imediata vecinătate a aşezării. Aşa se explică de ca o bună parte din ceramica din nivelul 3 este mai nisipoasă și arsă la o temperatură ceva mai ridicatăa ${ }^{15}$.

Porozitatea pastei a fost cercetată cu ajutorul porozităţii fragmentelor de vas ${ }^{16}$ şi comparată cu grosimea acestara.

La fragmentele ceramice de tipul 1 (ceramică netezită ornamentată sau nu cu şiruri de alveole, benzi aplicate şi protuberante) porozitatea variază între $6,5-16,8 \%$ pentru fragmente cu 6,3

\footnotetext{
${ }^{15}$ Curbele de absorbţie in infra-roşu ale suprafeţei unor fragmente ceramice descoperite in nivelul 3 Starcevo-Criş de la Şimnic nu prezintă banda de la $3690 \mathrm{~cm}^{-1}$ caracteristică caolinitului ceea ce dovedeşte o temperatură de peste $400^{\circ} \mathrm{C}$.

${ }^{16}$ Porozitatea a fost determinată prin absorb̧̧ia apei la temperatura ambiantă şi măsurată după 24 ore de contact apă-probă.
} 
- 15,4 mm grosime (fig. 4). Exceptând un fragment de vas cu 20,7\% porozitate, care este un defect de ardere, toate celelalte puocte reprezentative ocupă o suprafaţă de formă elipsoidală cu axa mare de $10 \%$ porozitate apropape paralelă cu ordonata graficului. Această repartiţie sugerează ça în reţeta de degresare nu s-a dat o atenţie prea mare la alegerea materialelor litologice pentru pastă şi nici a adausului de masă vegetală. Cu alte cuvinte nu erau selectate anumite luturi pentru confecţionarea acestui tip ceramic.

În grafic au fost separate trei suprafete corespunzătoare fragmentelor de buză, corp şi fund sau picior de vas. Statistic modelarea vaselor s-a fácut cu variaţii mari de porozitate a pereţilor vaselor și variaţii mai mici privind buza şi fundul sau piciorul lor. Arealul larg al punctelor corespunzătoare fragmentelor de corp de vas şi arealele mai restrânse pentru buza şi fundul sau piciorul lor arată că la modelarea ceramicei s-a insistat pe mulajul buzelor şi fundurilor sau picioarelor de vas şi că în diferite părţi ale vaselor au fost adăugate cantităţi diferite de maš̆ vegetală. Acest lucru dovedește că părţile vasului se alcătuiau

din bucăţi lipite şi mulate a căror cantitate de plante scădea în ordinea corp-buză-fund şi picior de vas.

Aceeaşi manieră de degresere se observă şi

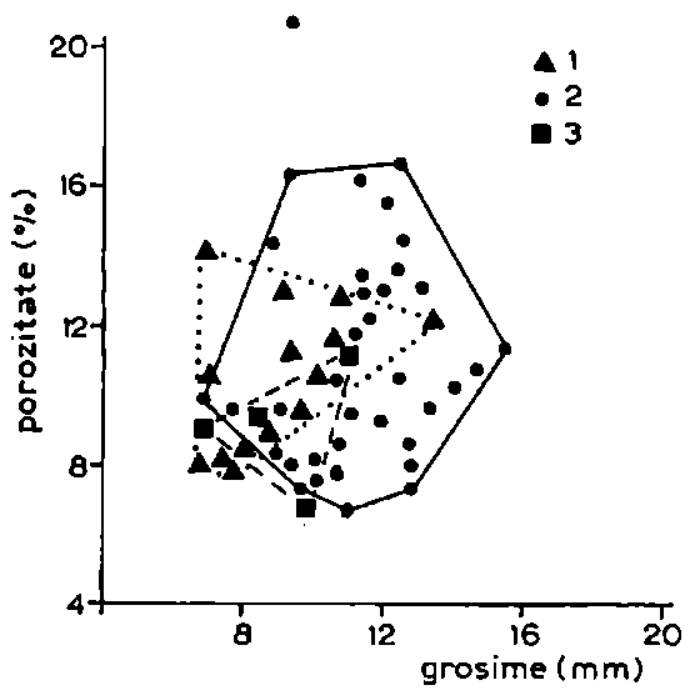

Fig. 4. Repartibia fragmentelor ceramice netezite şi ornamentate cu şirui de alveole, bráuri aplicate şi protuberante (bip 1) dupa porozitate și grosime: 1 buza, 2 - corp şi 3-fund sau picior de vas.

\section{la celelalte tipuri ceramice şi dovedeşte o reţetă}

stabilită şi transmisă prin tradiţie în întreg neoliticul timpuriu de la Şimnic.

Într-o diagrama porozitate-grosime (fig. 5) a fost prezentat numai conturul arealelor corespunzător ceramicii de tip 1 deja cercetate, al cerenicii cu vârci (tip 2) și al ceramicii cu amprente (tip 3). Cele două puncte exterioare arealului reprezintă fragmente cu fisuri și sunt defecte de ardere datorite rețetei de pastă greşite. Toate cele trei tipuri de ceramică au aproape acelaşi interval de variaţie a porozităţii şi confirmă o aceeaşi tehnică de degresare şi aceleaşi condiţii de amestecare a masei vegetale, aşa cum reiese din mărimea, forma şi repartiţia golurilor în secţiunile subţiri ale fragmentelor ceramice.

Arealul ceramicii cu vârci acoperă aproape întreg arealul ceramicii comune (tip 1) şi arată că cele două tipuri au aceeaşi tehnologie de pastă şi probabil aceeaşi mărime de vase.

Ceramica "mimetică" (tip 3) are un areal puţin deplasat spre porozităţi mai mici şi dovedeşte prin aceasta ç̆ a pus probleme tehnice mesterilor olari din neoliticul timpuriu de la Şimnic (arealul haşurat). Tendinţa lor de a modela paste cu porozităţi mai mici sugerează că modul de ornamentaţie a cerut adausuri mai mici de material vegetal mărunţit ceva mai temeinic şi luturi cu cât mai puţin nisip grosier.

În graficul din fig. 6 sunt reprezentate arealele ceramicii lustruite cu angobă roşie (tip 4) şi a ceramicii lustruite

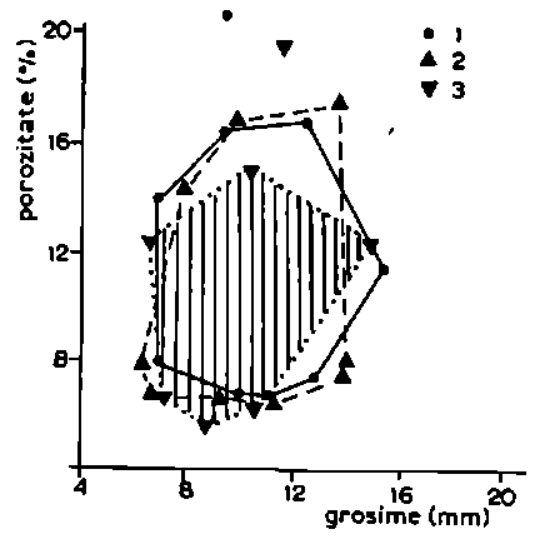

Fig. 5. Variatia porozitutiti cu grosimea unor fragmente ceramice: 1 -ceramică neterita (tip 1), 2-cu våra, 3-cu amprente fócute cu unghia. 
cu slip brun până la negru (tip 5) în comparaţe cu arealul ceramicei netezite (tip 1). Nu se observă diferenta de porozitate între aceste trei tipuri de ceramică, fapt care dovedeste că aplicarea unui slip sau a unei angobe roşii nu a cerut o soluţie deosebită a degresării pastei pentru a obţine 0 aderenţă adecvată pe vas a materialului mai fin de acoperire.

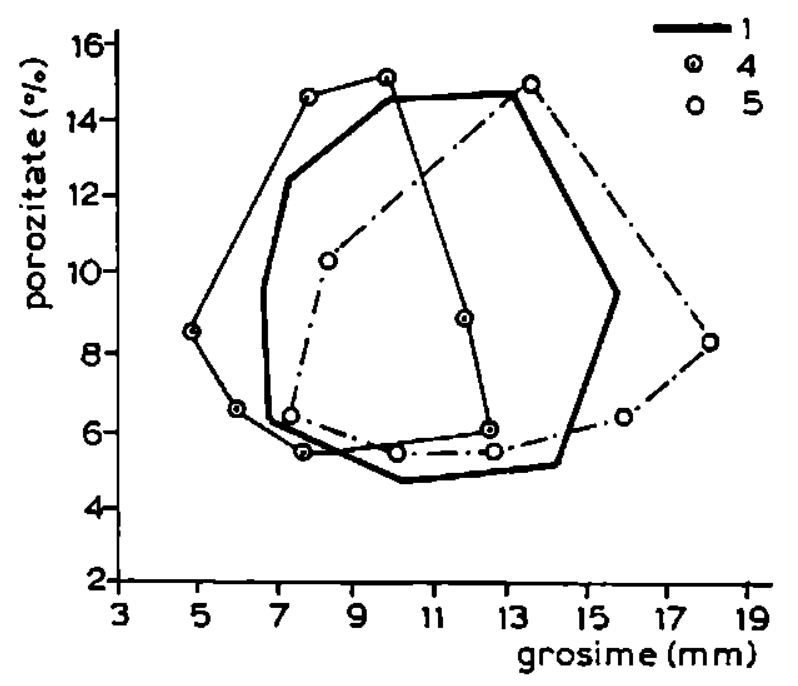

Fig. 6. Repartibia după porozitate şi grosime a fragmentelor ceramice: 4-lustruita cu angoba rossie, 5-lustruita cu slip, 1 - netezită (bip 1).

mai subţire decât ceramica netezită (tip 1).

Ceramica netezită (tip 1) şi ceramica lustruită cu slip (tip 5) au aproape aceleaşi limite de grosime, slipul din acelaşi material Cu argila din pastă având o bună aderenţă și un acelaşi coeficient de contracţie cu masa ceramică.

La ceramica lustruită cu angobă roşie diferențele de contracţie la uscare şi ardere a angobei şi a pastei au impus modelarea unor vase cu pereţi mai subţiri, aşa că arealul ceramicei cu angobă roșie este mult deplasat spre grosimi mai mici.

Soluţia micşorării grosimei pereţilor vaselor pentru aderenţa pe ceramica pictată a culorii de fond roşie (tip 6) sau deschisă (tip 7) reiese clar din figura 7 . Ceramica pictată este mai subţire decât ceramica cu angobă roşie şi mult

Dacă criteriul grosimii apreciazð̆ aderenţa culorii aplicate pe pereţi vaselor atunci această proprietate ar creşte în seria fond de culcare deschisă - fond roşu - angobă roșie - slip brun până la negru. Limitele de porozitate par să justifice această imagine. Ceramica pictată are limite de porozitate mai mari decât ceramica cu angobă roşie (fig. 7) şi sugerează o oarecare căutare şi nesiguranţ̆ în degresarea pastei ceramicei pictate. Soluţia evitării defectelor de ardere ca detaşarea culorilor de fond sau pictate sau

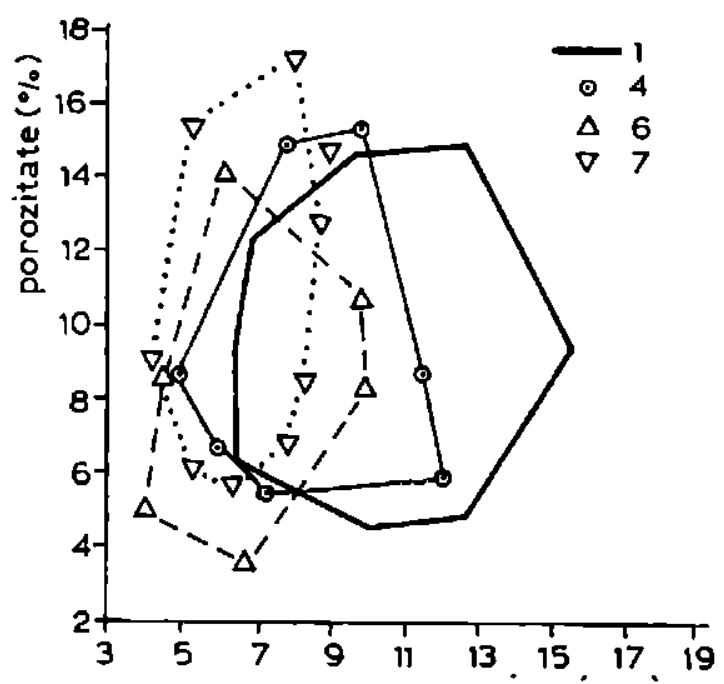

Fig. 7. Dependenţa porozităgii cu grosimea fragmentelor ceramice: ceramică netezita (tip 1), 4-lustruita $c u$ angoba rosie, 6 - pictata cu negru-brun pe fond rosu, 7 - pictata cu negru-brun pe fond de culaare deschisd. fisurarea pereţilor constă în modelarea unor vase cu pereţi mai subţiri şi probabil de dimensiuni mai reduse, aşa cum rezultă din grafic (fig. 7).

Variaţiile mari în porozitatea maselor ceramice, în modul de alegere a materialelor litologice şi în reţeta de degresare a pastei se datoreşte probabil unor întregi serii de meşteri olari din neoliticul timpuriu de la Şimnic. Fiecare meșter avea o anumită toleranţă în reproducerea retetei de pastă ceramică repetată mereu şi eventual modificată datorită experienţei personale şi probabil luturilor disponibile din deschiderile din timpul său. Reteta de pastă şi modificările sale eventuale erau transmise din generatiea în generaţie producând in timp variaţii ale tehnologiei de pastă. Este deja cunoscut că în nivelul 3 Starcevo-Criş de la Şimnic fragmentele de vase au o masă ceramică mai 
nisipoasă decât în celelalte două nivele. Rezultă că în lotul ceramicii analizate sunt cuprinse aceste variaţii ale tehnologiei de pastă împreună cu încercările reuşite sau nu şi cu eventualele modificări tehnologice. Atenuarea variaţiilor în timp a manierei de lucru a fiecărei generaţii de meşteri olari a fost fácută prin compararea valorilor medii de grosime, porozitate şi indice de porozitate ${ }^{17}$ a fiecărui tip de ceramiç̆ analizat.

Astfel variaţia porozităţi medii în funcţie de grosimea medie a fragmentelor de vas de un anumit tip (fig. 8) arată că punctele reprezentând cele şapte tipuri de ceramică Starcevo-Criş de la Şimnic se grupează în două regiuni, una pentru ceramica pictată şi cealaltă pentru restul ceramicii descoperite în aşezare.

Ceramica pictată este caracterizată prin grosime mai mică şi porozităţi mai mari a fragmentelor ceramice. Ceramica de uz comun (tip 1) şi cea cu vârci (tip 2) au puncte apropiate şi dovedesc o aceeaşi pastă ca porozitate şi grosime. Ceramica mimetică (tip 3) şi ceramica lustruită cu angobă roşie şi slip brun până la negru ocupă o poziţe intermediară în diagrama porozitate-grosimea pereţilor vaselor.

- $1 \Delta 2 \nabla 3 \odot 405 \Delta 6$

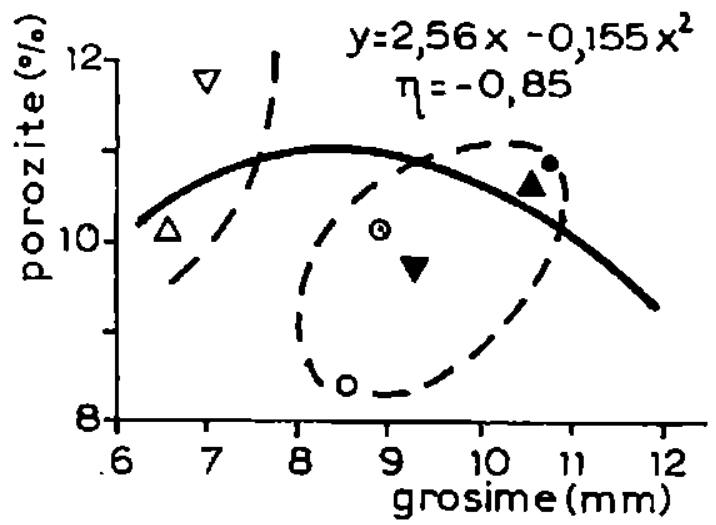

Fig. B. Repartigia dupa porozitate şi grosime a valorilor medii pe tip de ceramică: 1 - netezita (top 1), $2-c u$ varci, 3-cu amprente (tip 3), 4- lustruita cu angoba roşie, 5 - lustruita cu slip, 6 - pictată cu negru-brun pe rosu, 7 - pictatd cu negru-brun pe fond deschis.

Repartiţia probelor în grafic (fig. 8) sugerează problemele de pastă ridicate mesterilor olari neolitici. Rețeta de pastă stabilită pentru ceramica netezită (tip 1) şi ceramica cu vârci a fost utilizată cu mai multă atenţie la ceramica cu amprente (tip 3) şi cea lustruită (tip 4 şi 5) prin folosirea la degresarea unui material vegetal mai mărunţit şi probabil printr-o frământare mai temeinică. Soluţia tehnică adoptată pentru ceramica pictată a apelat la o degresare şi mai accentuată a pastei cu material vegetal bine mărunţit şi la o reducere mai accentuată a grosimii pereţilor vaselor. În acelaşi timp cu micsorarea pereţilor vaselor meşterii neolitici au ales surse pe cât posibil fără nisip grosier.

Un grafic care reprezintă indicele de porozitate în funcţie de grosime (fig. 9) separă şi mai bine ceramica cercetată în două areale distincte. De fapt indicele de porozitate reprezintă porozitatea pe milimetru grosime de fragment ceramic şi este o măsură a cantităţi de masă vegetală adăugată sursei de material litologic. Ceramica pictată este caracterizată de un adaus de masă vegetală în pastă mai mare şi de modelarea unor vase cu pereţi mai subţiri faţă de restul ceramicei Starcevo-Criş de la Şimnic. Repartiţia punctelor în diagramă arată că dimensiunile medii ale celor şapte tipuri de ceramică netezită şi ornamentată cu şiruri de alveole, brâuri de aplicaţii, protuberanţe şi incizii uşoare, la ceramica cu vârci, ceramica lustruită cu angobă roşie san cu slip brun până la negru şi ceramica pictaťr. Această succesiune sugerează şi accentuarea grijei în alegerea surselor, obţinerea pastei prin degresare cu masă vegetală precum şi ornamentare.

\footnotetext{
${ }^{17}$ Indicele de porozitate a unei mase ceramice este valoarea raportului dintre porozitate exprimata in \% şi grosimea fragmentelor ceramice exprimata in $\mathrm{mm}$.
} 
Această ipoteză este întărită de aşezarea punctelor reprezentative de-a lungul unei drepte $y=2,64-0,16 x$ (unde $y$ este indicele de porozitate mediu şi $x$ grosimea medie a fiecărui tip de ceramică Starcevo-Criş din aşezare) cu coeficient de corelaţie ridicat $(r=-0,874)$.

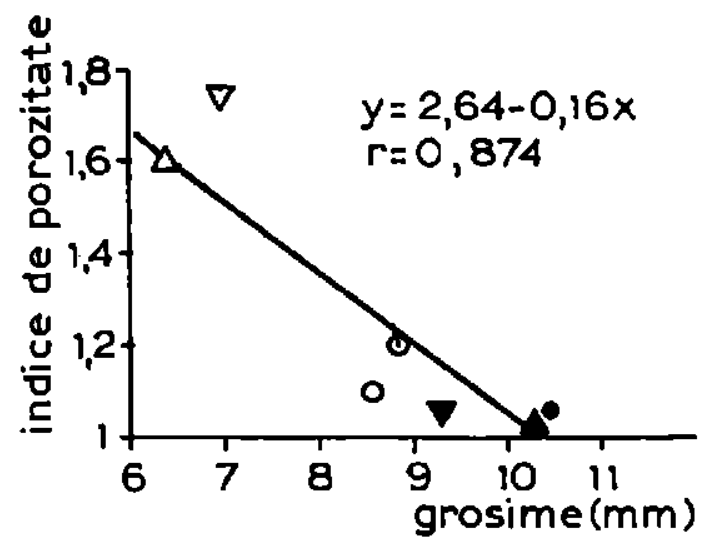

Fig. 9. Repartibia după indicele de porozitate s/ grosimea fragmentelor Starcevo-Criş de la șimnic. Aceleaşi notaţii ca în fig. 8.

Examinarea secţiunilor subţiri arată ca pentru pasta ceramicii lustruite şi pictate au fost alese materiale litologice pe cât posibil lipsite de nisip grosier, astfel încât în general masa lor ceramică este aparent mai fină decât a ceramicei netezite deşi pasta are o cantitate apreciabila de nisip fin.

Astfel datele analitice evidenţiază o singură tehnologie de pastă cu degresare cu masă vegetală cu două rețete, una cu adausuri accentuate de masă vegetală mult mărunţită caracteristică ceramicii pictate şi o a două rețetă cu un adaus moderat de masă vegetală mărunţită mai puţin şi folosită pentru restul ceramicii din neoliticul timpuriu de la Şimnic.

Diferentele de degresare a pastei cu material vegetal mărunţit sugerează că mesterii olari neolitici pregăteau pasta ceramică pentru anumite tipuri de vase. Încă de la alegerea materialului litoligic mesterul olar stabilea reteta de degresare pentru a realiza vase pictate sau vase lustruite. Pentru ceramica netezită alegerea materialului litologic şi degresarea pastei cu material vegetal cerea o mai mičr atenţie.

\section{Concluzil}

Pentru cercetarea tehnologiei de pastă a ceramicei Starcevo-Criş de Şimnic materialele ceramice au fost împarrţite în şapte tipuri dupð̆ ornamentaţie şi prelucrarea feţelor vaselor.

Surse pentru pastă au fost materialele litologice locale cu texturi de la lut-nisipoase la lutargiloase.

Meșterii olari din neoliticul timpuriu de la Şimnic au adus tehnologia de pastă din alte aşezări Starcevo-Criş cu surse argiloase şi au adaptat-o la sursele de pastă locale. În decursul timpului s-a manifestat o preferinţă pentru o pastă mai nisipoasă şi odată cu ridicarea temperaturii de ardere în niveluł 3 o bună parte din masele fragmentelor ceramice sunt mai grezoase şi mai aspre la pipăit.

Porozitatea care apare ca un mijloc de evidenţiere a degresării pastei prezintă variaţii mari la acelaşi tip de ceramică şi dovedește că adausul vegetal era fácut empiric după experienţa fiecărui mester olar neolitic cu deosebiri mari de la mester la meşter şi de la generaţie la generaţie. Variaţia mare de porozitate reprezintă deci căutările, variaţia reţetei de degresare în timp şi poate nesiguranţa meșterilor olari din neoliticul timpuriu de la Şimnic.

Sursele de material litologic din imediato apropiere a aşezării au limite de variaţie mai mari a conţinutului de nisip decât masa fragmentelor ceramice şi exclud prin aceasta folosirea nisipului ca degresant. 
La acelaşi tip de ceramică porozitatea creşte în ordinea fund sau picior-buză-corp şi dovedeste modul inegal de adăugare al materialului vegetal la diferite fărţi ale vaselor.

Poziţia arealelor fiecărui tip de ceramică într-o diagramă într-o diagramă porozitate-grosimea fragmentelor ceramice (fig. 5-6 şi 7) arată că degresarea ceramicii netezite (tip 1 şi 2) şi a ceramicii lustruite cu slip (tip 5) a fost asemănătoare şi nu a pus probleme mesterilor olari neolitici. Ceramica cu amprente (tip 3) are limite de porozitate deplasate spre porozităţi mai mici probabil din cauza ornamentaţiei. La ceramica lustruită cu angobă roşie (tip 4) şi la ceramica pictată soluţia tehnică adoptată pentru aderența aplicaţiei de culoare pe pereţii vaselor constă în micsorarea grosimei pereţilor şi mărunţirea mai temeinică a degresantului vegetal adăugat în cantitate mai mare însoţită de alegerea unei surse mai argiloase şi pe cât posibil fără nisip grosier.

Atenuarea diferenţelor datorite generaţiilor de meşteri olari prin medii caiculate pentru fiecare tip de ceramică a arătat (fig. 8 şi 9) că porozitatea, indicele de porozitate şi grosimea fragmentelor separă net două reţete de degresare, una pentru ceramica pictată şi alta pentru restul ceramicei Starcevo-Criş de la Şimnic. Relaţile semnificativ matematice porozitate-grosime şi indice cle porozitate -grosine arată o singură tehnologie de pastă şi anume degresarea cu material vegetal mărunţit.

Datele analitice sugerează că încă de la alegerea materialului litologic şi degresarea pastei meşterul olar din neoliticul timpuriu de la Şimnic hotăra tipul de ceramică pe care avea de gând să-l modeleze.

\section{The paste technology of Starcevo-Criş pottery from Şimnic}

\section{Summary}

On order to investigate the technology, Starcevo-Criş pottery discovered at Şimnic was distributed in seven types according to its ornamentation and processing of the vessel faces.

The sources of ceramic paste were local lithological materials with a texture from sandy loam to clay loam. The potters of the early neolithic at Şimnic brought the paste technology from other Starcevo-Criş settlement with sources more clayey and adapted it to the local sources. During the early neolithic time there was a preference to use more and more a paste more sandy, especially in the last part of Starcevo-Criş culture at Şimnic.

The vessel porosity present a large variation for the same ceramic type and this proves an empirical plant addition made according to the experience of each neolithic potter with large differences from one to another and from a generation to another. The large variation in porosity represents therefore the atemps, the evolution in paste processing during the time and posiible the incertitude from early neolithic potters at Şimnic.

The local sources of the lithologic material situated in the perimeter of the settlement have more large variation limits of the sand content than the ceramic sources for the paste.

In the same ceramic type the porosity increase in order bottom or leg-rim-body and proves the unequal manner of the plant material addition to the different part of the vessed. 
The area position of the each ceramic type in a graph porosity-shard tickness (fig 5-6-7) show the same plant addition to the common pottery (type 1 and 2) and to the polished ceramics with brown to black colour slip (type 5). The ceramics decorated with fingerprints (type 3) have porosity limits displaced to small value due probably to the ornamentation. At the polished pottery with red application (type 4) and specially at painted ceramics the technical solutions taken for the adherence of the colour applications on pottery walls were the selection of one more clayey lithological material if possible without coarse sand.

By means of the values of each ceramic type were obtained some statistical correlation between porosity-thickness and porosity index-thickness of the shards. The point distribution in two regions of the graphs show a single paste technology with the plant addition but two paste processing one for the painter ceramics and the another for the rest of Starcevo-Criş pottery at Şimnic.

\section{Figures}

Fig. 1. Distribution of the investigated samples in regard to their $\mathrm{Mg} / \mathrm{Sr}$ and $\mathrm{Ca} / \mathrm{Fe}$ ratios: 1 common smooth pottery (type 1); 2 - with "vârci"; 3 - with fingerprints; 4 - polished with red application; 5 - polished with "slip" brown to black; 6 - painted with black-brown colour on red; 7 painted with black-brown on light colour.

paste sources: 8 - sandy loam; 9 - loam; 10 - clay loam.

- source area, _ _ _ smooth pottery (types 1-2-3), .... polished pottery area (types 4-5-6-7)

Fig. 2. Distribution of sources and Starcevo-Criş shards at Şimnic in regard to their contents in fine and coarse sand: 1 - sources; fingerprint ceramics (type 3); 2 - level $1 ; 3$-level $2 ; 4-$ level 3; painted ceramics with black-brown on red; 5 - level 1,6-level 2, 7- level 3.

Fig. 3. Variation of smectite content as a function of clay content (under $0,002 \mathrm{~mm}$ ) at paste sources in the neolitic time at Şimnic.

Fig. 4. Distribution of the smooth ceramic shards (type 1) in regard to their porosity and thickness: 1 - rim, 2 - body, 3 - bottom or leg.

Fig. 5. Relationship between porosity and shard thicknees: 1 - common smooth pottery (type 1), 2 - with "vârci", 3 - with fingerprints (type 3).

Fig. 6. Dependence of the porosity upon the shard thickness: 4 - polished pottery with red application, 5 - polished with a brown to black slip, 1 - common smooth ceramics.

Fig. 7. Distribution of the porosity in regard to their Starcevo-Criş pottery thickness: common smooth ceramics (type 1), 4-polished with red application, 6 - painted with brown-black on red, 7 - painted with brown-black on light colour.

Fig. 8. Relationship between mean porosity and mean tickness of each type of the pottery: 1 - common smooth ceramics (type 1), 2 - with "Vârci", 3 - fingerprints (type 3), 4 - polished with red application, 5 - polished with "slip", 6 - painted with black-brown on red, 7 - painted with blackbrown on light colour.

Fig. 9. Distribution of Starcevo-Cris pottery in regard to their mean porosity and mean thickness. The same notation as in figure 8. 